\title{
TRANSPORT AND INTERACTIONS OF SULFAPYRIDINE IN AGAROSE HYDROGELS ENRICHED BY HUMIC ACIDS
}

\author{
${ }^{1}$ Martina KLUČÁKOVÁ \\ ${ }^{1}$ Brno University of Technology, Faculty of Chemistry, Brno, Czech Republic, EU, klucakova@fch.vutbr.cz
}

https://doi.org/10.37904/nanocon.2021.4368

\begin{abstract}
Knowledge of behaviour of pharmaceuticals as contaminants in nature is essential for their mobility and toxicity in the soils and surface- and ground-water environments. Their migration ability and toxicity can be affected by their interactions with organic matter. In this contribution, sulfapyridine (a sulfanilamide drug used for antibacterial medication) is studied from the point of view of its transport in hydrogels containing humic substances. Agarose hydrogel was used as a model medium for the transport experiments. Standard Elliot soil humic acid $(4 \mathrm{~S} 102 \mathrm{H})$ purchased from International Humic Substances Society was incorporated into the hydrogel as an active nanomaterial for interactions with drug and potential suppression of their migration and toxicity in soil systems. The method of diffusion couple was applied on the diffusion experiments. Donor part was saturated by sulfapyridine and acceptor part was free of drug. After connecting of both parts, the time development of concentration profiles in the couple was monitored. The effective diffusion coefficients for the transport of sulfapyridine in hydrogel enriched by humic acids and pure agarose hydrogel were determined and compared. It was found that the transport of drug is influenced by interactions with humic acids which can immobilize partially sulfapyridine in humic structure. Simultaneously, sorption/desorption experiments were realized. Their results confirmed high degree of drug immobilization (60-90\% in the dependence on drug concentration).
\end{abstract}

Keywords: Sulfapyridine, humic acids, agarose hydrogel, diffusion, interaction

\section{INTRODUCTION}

The use of many different pharmaceuticals in human and veterinary medicine and their persistence can result in potential dangerous behaviour in soil and aqueous environments [1-5]. Drugs are not completely eliminated, therefore their residues leave the body and pass into water, sediments and soils [6-12]. The degradation of drugs are very different in the dependence on their chemical character and physicochemical circumstances. An important role is attributed to soil properties and quality of organic matter. The migration ability and toxicity of pharmaceuticals in nature can be significantly affected by their interactions with soil components.

Humic substances as important constituent of soil organic matter can form complexes with drugs of different strengths therefore strongly bond, ion exchangeable and extractable fractions of complexes co-exist in nature $[5,13,14]$. The binding character varies between electrostatic interactions, hydrogen bonds and hydrophobic interactions [5,13-18]. Sulfonamides are one of the most commonly used antibiotic in human and veterinary medicine. Their overuse and misuse led to their widespread occurrence in nature [19-21], e.g. their representative - sulfapyridine - is one of the most frequently antibiotics detected in wastewater effluents and surface waters [22-24]. They reach agricultural soils via contaminated sewage sludge, wastewater, and manure used for fertilization [25-27]. The occurrence, fate, ecotoxicity and uptake of antibiotics by edible crops were described in detail in thorough reviews [28-30]. Studies on interactions of, soil, organic matter and humic substances with antibiotics are focused mainly on adsorption processes [31-35]. Chen et al. [31] studied the adsorption of sulfamethoxazole and sulfapyridine on peat soil and composted manure. They resulted that 
content of organic carbon greatly enhanced their adsorption on the soil and suggested the hydrophobic partition as the major mechanism. The pyridine group was mainly responsible for the adsorption at high $\mathrm{pH}$ values (in the case of sulfapyridine). Haham et al. [32] investigated sorption-desorption behavior of sulfapyridine with three different soils. The showed important roles of soil mineral matrices and dissolved organic matter. Similarly, the important effect of dissolved organic matter on the adsorption of sulfonamides on graphene oxides was observed by Liu et al. [33]. Thiele-Bruhn et al [34] studied sorption of sulfonamides on whole soils and their particle-size fractions. According to their results, the adsorption increased with aromaticity and electronegativity of functional groups attached to the sulfonyl-phenyl-amine core. Modeling and molecular mechanics calculations showed preferred site-specific sorption via hydrogen bonds and van der Waals interactions. Thiele [35] investigated the adsorption of sulfapyridine on Chernozem. They observed that the adsorption was substantially higher in moist soil in comparison with dried sample. They concluded also that the $\mathrm{N}$-heterocycle significantly contributed to the adsorption of sulfapyridine.

Zhi et al. [36] stated that traditional adsorption models (Langmuir, Freundlich) cannot exhibit their behavior under different influencing conditions. Thus, they are not able to reflect the precise adsorption mechanism of antibiotics in soil. Schwarz et al. [25] concluded that the mechanism of immobilization of sulfapyridine varied from reversible sorption to the formation of non-extractable bound residues. The character of interactions, immobilization degree and mobility of antibiotics in nature thus are significantly influences by soil properties and character of organic matter [31,34,37].

Our approach is different. The contribution is focused on the diffusivity of sulfapyridine in model hydrogel matrix and the effect of humic substances incorporated in hydrogel on the migration of the antibiotics. The study is based on our previous experiences with diffusion experiments of different pollutants in hydrogel matrices containing humic substances [38,39] and the effect of the interactions on the mobility [40-43]. The method of diffusion couple [38] was chosen for the investigation of humic-drug interactions effect on the mobility of sulfapyridine in model hydrogel based on agarose enriched by humic acids $[39,41]$.

\section{MATERIALS AND METHODS}

Sulfapyridine (as sulfonamide antibotics) and agarose (routine use class) were purchased from Sigma-Aldrich. Elliot soil humic acids $(4 \mathrm{~S} 102 \mathrm{H})$ were purchased from the International Humic Substances Society. The main characteristics of humic acids (e.g. elemental composition or the contents and properties of acidic functional groups) can be found on the website of the International Humic Substances Society.

The preparation of hydrogels was based on the thermo-reversible gelation of agarose solution. It was dissolved in deionized water ( $1 \% \mathrm{wt}$.), heated at $80^{\circ} \mathrm{C}$ and stirred, and finally sonicated to remove gasses. Afterwards, the solution was slowly poured into the PMMA spectrophotometric cuvette. Its orifice was immediately covered with pre-heated plate of glass to prevent drying and shrinking of gel. Flat surface of the boundary of resulting hydrogels was provided by wiping an excess solution away. Gentle cooling of cuvettes at the laboratory temperature led to the gradual gelation of the mixture. Hydrogels enriched by humic acids were prepared from $1 \%$ wt. agarose solution containing $0.01 \%$ wt. of humic acids. Donor hydrogels were prepared by means of agarose (1\% wt.) dissolved in $1 \mathrm{mM}$ sulfapyridine solution.

The diffusion couple was assembled from two parts: donor and acceptor hydrogels. Donor hydrogel was formed from agarose containing sulfapyridine as diffusing drug particles. Acceptor hydrogels were based on agarose or agarose enriched by humic acids without antibiotics (their initial concentrations in acceptor hydrogels were equal to zero).

The distributions of sulfapyridine in donor and acceptor hydrogels were determined in selected time intervals. The cuvettes were disconnected and the UV-VIS spectra were measured at various distances from the orifice by means of Varian Cary 50 UV-VIS spectrophotometer equipped with the special accessory providing controlled fine vertical movement of the cuvette in the spectrophotometer. Using the collected UV-VIS spectra, 
the concentrations of drug were determined at different positions in hydrogels. The obtained data were used to compute the concentration profiles of drug in the donor and acceptor parts of diffusion couple. The diffusion fluxes in given times were determined as the total contents of sulfapyridine in acceptor hydrogel (normalized on the area of interface). The content of drug in acceptor hydrogel at given time should be the same as the decrease in drug content in the donor part of diffusion couple.

Sorption experiments were realized with sulfapyridine solutions with concentration range $1-10 \mathrm{mg}^{-\mathrm{dm}^{-3}}$. Solid humic hamic (in form of powder) were mixed with the drug solution $\left(1 \mathrm{~g} / 50 \mathrm{~cm}^{3}\right)$ and stirred. After equilibration (48 h), the powder was centrifuged and mixed with deionized water in order to determine the amount of extractable (mobile) phase of sulfapyridine. The decrease in concentration of drug solutions as well as the concentration of leachates were determined by means of UV/VIS spectrometry (see above).

All experiments were triplicated and performed at laboratory temperature $\left(25 \pm 1^{\circ} \mathrm{C}\right)$. Data are presented as average values with standard deviation bars.

\section{RESULTS AND DISCUSSION}

In this work, the effect of humic-drug interaction on the diffusivity of sulfapyridine in agarose hydrogels were studied. In Figure 1 the example of experimental data obtained after 4 days are shown. We can see that the crossing of drug particles from donor hydrogel into acceptor hydrogels with and without of humic acids are different. As assumed, the presence of humic acids as active substance can cause interactions between their binding sites and sulfapyridine which can result in a partial immobilization of drug particles. The effect of humicdrug interactions should be more noticeable for longer times of diffusion. The mathematical description of realized experiments were based on second Fick's law valid for non-stationary diffusion [38,40-43]. In the case of diffusion couple, the boundary conditions of semi-infinite mediums and equality between the decrease in drug content in donor hydrogel and the increase in drug content in acceptor hydrogel in given time were applied. The concentration at interface between both hydrogels was equal to the half of initial donor concentration. The initial boundary condition was the homogeneous initial concentration of drug in donor hydrogel $\left(c_{0}\right)$ and zero initial concentrations of sulfapyridine in acceptor hydrogels.

The mathematical solution of the second Fick's law is

$c(x, t)=\frac{1}{2} c_{0} \operatorname{erfc} \frac{x}{\sqrt{4 D_{\mathrm{ef}} t}}(1)$

and the equation for the total diffusion flux $m_{\mathrm{t}}$ which goes through the interface between donor and acceptor hydrogels $(x=0)$ in time $t$ can be expressed as

$m_{t}=c_{0} \sqrt{\frac{D_{\mathrm{ef}} t}{\pi}}$

The effective diffusion coefficient $D_{\text {ef }}$ is the main parameter characterizing rate of the diffusion process. It allows for two main factors: the tortuous movement of the diffusing particles in the porous structure of hydrogel and interactions of diffusing particles with active components incorporated in hydrogels. If we assume a local equilibrium between free mobile drug and immobilized particles, its equilibrium constant $K$ can be expressed as the radio between concentrations of immobilized and free sulfapyridine and involved into the value of $D_{e f}$ :

$D_{e f}=\frac{D_{0}}{1+K}$

Diffusion coefficients for of drug for pure agarose hydrogel and hydrogel enriched by humic acids were determined by means of equation 2 . In this contribution, $D_{0}$ thus represents the diffusivity of drug particles in non-reactive agarose hydrogel (without humic acids) and $D_{\text {efinvolves the influence of interactions. Their values }}$ 
were calculated as $D_{0}=1.01 \times 10^{-10} \mathrm{~m}^{2} \cdot \mathrm{s}^{-1}$ and $D_{\text {ef }}=9.85 \times 10^{-11} \mathrm{~m}^{2} \cdot \mathrm{s}^{-1}$. The equilibrium constant $K$ is then (according to equation 3 ) equal to 0.37 .
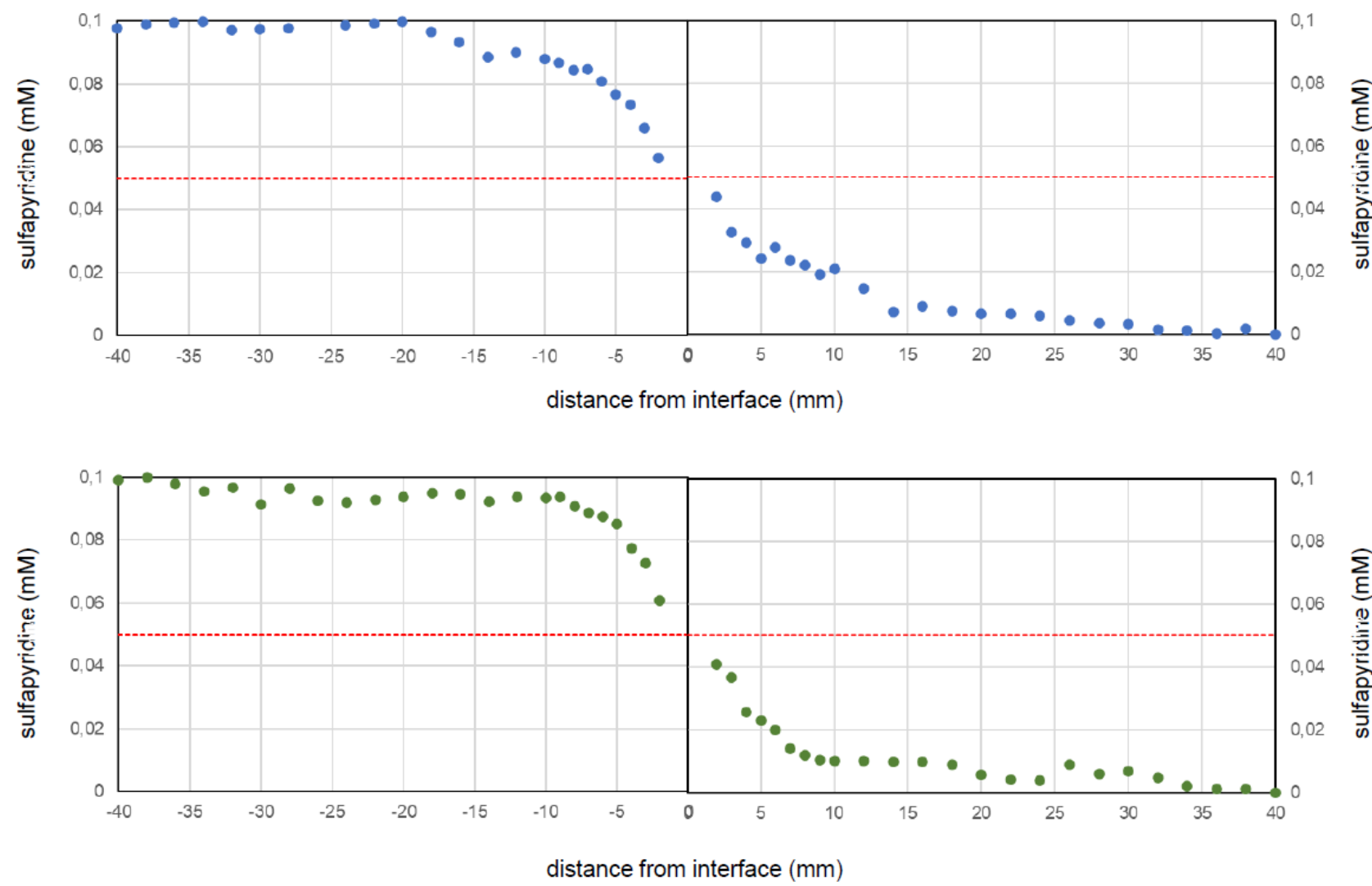

Figure 1 The concentration profiles of sulfapyridine in the diffusion couple formed from donor hydrogel and acceptor hydrogels based on pure agarose (blue) and agarose enriched by humic acids (green) after 4 days. Dashed lines (red) represent theoretical homogeneous concentration of sulfapyridine after attainment of equilibrium.

Adsorption/desorption experiments showed that humic acids are able to immobilize sulfapyridine with adsorption capacity $0.28 \mathrm{mg} \cdot \mathrm{g}^{-1}$ (based on Langmuir adsorption isotherm [44]). The desorption experiments showed that the content of mobile fraction increased from $16.4 \%$ (for initial concentration of $1 \mathrm{mg}^{-\mathrm{dm}^{-3}}$ ) up to $38.5 \%$ (for $10 \mathrm{mg}^{-\mathrm{dm}^{-3}}$ ). It means that humic acids were able to strongly bind a majority of drug and its percentage decreased as the capacity of humic acids were gradually saturated.

\section{CONCLUSION}

In this work, the diffusivity of sulfapyridine in model hydrogels was studied. The diffusion couple was formed by donor agarose hydrogel with incorporated drug particles and acceptor hydrogel with initially zero drug concentration. Two types of acceptor hydrogel (with and without humic acids) were used in order to investigate the influence of humic-drug interactions on the mobility of sulfapyridine. It was found that drug particles were partially immobilized by the interactions which resulted in lower value of effective diffusion coefficient. The percentage of non-leachable drug fraction achieved $60-80 \%$ in the dependence on the total drug content.

\section{REFERENCES}

[1] RICHARDSON, S.D., TERNES, T.A. Water analysis: emerging contaminants and current issues. Analytical Chemistry. [online]. 2005, vol. 77, pp. 3807-3838. Available from: https://doi.org/10.1021/acs.analchem.7b04577. 
[2] FENT, K., WESTON, A.A., CAMINADA, D. Ecotoxicology of human pharmaceuticals. Aquatic Toxicology. [online]. 2006, vol. 76, pp. 122.159. Available from: https://doi.org/10.1016/j.aquatox.2005.09.009.

[3] SCHLÜSENER, M.P., BESTER, K. Persistence of antibiotics such as macrolides, tiamulin and salinomycin in soil. Environmental Pollution. [online]. 2006, vol. 143, no. 3, pp. 565-571. Available from: https://doi.org/10.1016/i.envpol.2005.10.049.

[4] CUNNINGHAM, V.L., BINKS, S.P., OLSON, M.J. Human health risk assessment from a presence of human pharmaceuticals in the aquatic environment. Regulatory Toxicology and Pharmacology. [online]. 2009, vol. 53, pp. 39-45. Available from: https://doi.org/10.1016/j.yrtph.2008.10.006.

[5] KLAVINS, M., ANSONE, L., PURMALIS, O., ZICMANIS, A. Characterization of interaction between tricyclic structures containing pharmaceuticals, their model and humic substances. Water Science \& Technology. [online]. 2011, vol. 63, pp. 845-852. Available from: https://doi.org/10.2166/wst.2011.119.

[6] SACHER, F., LANGE, F., BRAUCH, H., BLANKENHORN, I. Pharmaceuticals in groundwaters: Analytical methods and results of a monitoring program in Baden-Württemberg, Germany. Journal of Chromatography A. [online]. 2001, vol. 938, pp. 199-210. Available from: https://doi.org/10.1016/S0021-9673(01)01266-3.

[7] JUX, U., BAGINSKI, R., ARNOLD, H.G., KRÖNKE, M., SENG P.N. Detection of pharmaceutical contaminations of river, pond, and tap water from Cologne (Germany) and surroundings. International Journal of Hygiene and Environmental Health. [online]. 2002, vol. 205, pp. 393-398. Available from: https://doi.org/10.1078/1438-4639$\underline{00166 .}$.

[8] KIM, S.C., CARLSON, K. LC-MS2 for quantifying trace amounts of pharmaceutical compounds in soil and sediment matrices. Trends in Analytical Chemistry. [online]. 2005, vol. 24, pp. 635-644. Available from: https://doi.org/10.1016/j.trac.2005.04.006.

[9] SIM, W., LEE, J., OH, J. Occurrence and fate of pharmaceuticals in wastewater treatment plants and rivers in Korea. Environmental Pollution. [online]. 2010, vol. 158, pp. 1938-1947. Available from:

https://doi.org/10.1016/i.envpol.2009.10.036.

[10] ÁLVAREZ-RUIZ, R., ANDRÉS-COSTA, J.M., ANDREU, V., PICÓ, Y. Simultaneous determination of traditional and emerging illicit drugs in sediments, sludges and particulate matter. Journal of Chromatography A. [online]. 2015, vol. 1405, pp. 103-115. Available from: https://doi.org/10.1016/j.chroma.2015.05.062.

[11] KOBA, O., GOLOVKO, O., KODEŠOVÁ, R., FÉR, M., GRABIC, R. Antibiotics degradation in soil: A case of clindamycin, trimethoprim, sulfamethoxazole and their transformation products. Environmental Pollution. [online]. 2017, vol. 220, pp. 1251-1263. Available from: https://doi.org/10.1016/..envpol.2016.11.007.

[12] MONTEIRO, S.C., BOXALL, A.B.A. Factors affecting the degradation of pharmaceuticals in agricultural soils. Environmental Toxicology and Chemistry. [online]. 2009, vol. 28, pp. 2546-2554. Available from: https://doi.org/10.1897/08-657.1.

[13] KHIL'KO, S.L., SEMENOVA, R.G. Interaction of humic acid salts with drug preparations. Solid Fuel Chemistry. [online]. 2016, vol. 50, pp. 60-64. Available from: https://doi.org/10.3103/S0361521916060057.

[14] LIN, K., GAN, J. Sorption and degradation of wastewater-associated non-steroidal anti-inflammatory drugs and antibiotics in soils. Chemosphere. [online]. 2011, vol. 83, pp. 240-246. Available from: https://doi.org/10.1016/i.chemosphere.2010.12.083.

[15] MARGON, A., PASTRELLO, A., MOSETTI, D., CANTONE, P., LEITA, L. Interaction between diclofenac and soil humic acids. Soil and Sediment Contamination. [online]. 2009, vol. 18, pp. 489-496. Available from: https://doi.org/10.1080/15320380902962353.

[16] MARTíNEZ-MEJÍA, M. J., SATO, I., RATH, S. Sorption mechanism of enrofloxacin on humic acids extracted from Brazilian soils. Environmental Science and Pollution Research. [online]. 2017, vol. 24, pp. 15995-16006. Available from: https://doi.org/10.1007/s11356-017-9210-3.

[17] LIU, X., LU, S., LIU, Y., MENG, W., ZHENG, B. Adsorption of sulfamethoxazole (SMZ) and ciprofloxacin (CIP) by humic acid (HA): characteristics and mechanism. RCS Advances. [online]. 2017, vol. 7, pp. 50449-50458. Available from: https://doi.org/10.1039/C7RA06231A.

[18] PARK, J., CHO, K.H., LEE, E., LEE, S., CHO, J. Sorption of pharmaceuticals to soil organic matter in a constructed wetland by electrostatic interaction. Science of the Total Environment. [online]. 2018, vol. 435, pp. 1345-1350. Available from: https://doi.org/10.1016/i.scitotenv.2018.04.212. 
[19] KÜMMERER, K. Antibiotics in the aquatic environment - A review - Part I. Chemosphere. [online]. 2009, vol. 75, pp. 417-434. Available from: https://doi.org/10.1016/j.chemosphere.2008.11.086.

[20] MANZETTI, S., GHISI, R. The environmental release and fate of antibiotics. Mar. Pollut. Bull. [online]. 2014, vol. 79, pp. 7-15. Available from: https://doi.org/10.1016/j.marpolbul.2014.01.005.

[21] MARTíNEZ, J.L. Antibiotics and antibiotic resistance genes in natural environments. Science [online]. 2008, vol. 321, pp. 365-367. Available from: https://doi.org/10.1126/science.1159483.

[22] GARCÍA-GALÁN, M.J., VILLAGRASA, M., DIAZ-CRUZ, M.S., BARCELO, D. LC-QqLIT MS analysis of nine sulfonamides and one of their acetylated metabolites in the Llobregat River basin. Quantitative determination and qualitative evaluation by IDA experiments. Anal. Bioanal. Chem. [online]. 2010, vol. 397, pp. 1325-1334. Available from: https://doi.org/10.1007/s00216-010-3630-y.

[23] PENG, X., WANG, Z., KUANG, W., TAN, J., LI, K. A preliminary study on the occurrence and behavior of sulfonamides, ofloxacin and chloramphenicol antimicrobials in wastewaters of two sewage treatment plants in Guangzhou, China. Sci. Total Environ. [online]. 2006, vol. 371, pp. 314-322. Available from: https://doi.org/10.1016/j.scitotenv.2006.07.001.

[24] LIU, H., ZHANG, B., LI, Y., FANG, Q., HOU, Z., TIAN, S., GU, J. Effect of radical species and operating parameters on the degradation of sulfapyridine using a UV/chlorine system. Ind. Eng. Chem. Res. [online]. 2020, vol. 59, pp. 1505-1516. Available from: https://doi.org/10.1021/acs.iecr.9b06228.

[25] SCHWARZ, J., KNICKER, H., SCHAUMANN, G.E., THIELE-BRUHN, S. Enzymatic transformation and bonding of sulfonamide antibiotics to model humic substances. J. Chem. [online]. 2015, vol. 2015, ID 892708. Available from: https://doi.org/10.1155/2015/829708.

[26] BOXALL, A.B., FOGG, L.A., BLACKWELL, P.A., KAY, P., PEMBERTON, E.J., CROXFORD, A. Veterinary medicines in the environment. Rev. Environ. Contam. Toxicol. [online]. 2004, vol. 180, pp. 1-91. Available from: https://doi.org/10.1007/0-387-21729-0 1.

[27] KIM, K.R., OWENS, G., KWON, S.I., SO, K.H., LEE, D.B., OK, Y.S. Occurrence and environmental fate of veterinary antibiotics in the terrestrial environment. Water Air Soil Pollut. [online]. 2011, vol. 214, pp. 163-174. Available from: https://doi.org/10.1007/s11270-010-0412-2.

[28] PAN, M., CHU, L.M. Fate of antibiotics in soil and their uptake by edible crops. Sci. Total Environ. [online]. 2017, vol. 599-600, pp. 500-512. Available from: https://doi.org/10.1016/i.scitotenv.2017.04.214.

[29] DU, L. LIU, W. Occurrence, fate, and ecotoxicity of antibiotics in agro-ecosystems. A review. Agron. Sustain. Dev. [online]. 2012, vol. 32, pp. 309-327. Available from: https://doi.org/10.1007/s13593-011-0062-9.

[30] WANG, S., WANG, H. Adsorption behavior of antibiotic in soil environment: a critical review. Front. Environ. Sci. Eng. [online]. 2015, vol. 9, pp. 565-574. Available from: https://doi.org/10.1007/s11783-015-0801-2.

[31] CHEN, K.L., LIU, L.C., CHEN, W.R. Adsorption of sulfamethoxazole and sulfapyridine antibiotics in high organic content soils. Environ. Pollut. [online]. 2017, vol. 231, pp. 1163-1171. Available from:

https://doi.org/10.1016/j.envpol.2017.08.011.

[32] HAHAM, H., OREN, A., CHEFETZ, B. Insight into the role of dissolved organic matter in sorption of sulfapyridine by remiarid Soils. Environ. Sci. Technol. [online]. 2012, vol. 46, pp. 11870-11877. Available from: https://doi.org/10.1021/es303189f.

[33] LIU, F.F., ZHAO, J., WANG, S., XING, B. Adsorption of sulfonamides on reduced graphene oxides as affected by $\mathrm{pH}$ and dissolved organic matter. Environ. Pollut. [online]. 2016, vol. 210, pp. 85-93. Available from: https://doi.org/10.1016/j.envpol.2015.11.053.

[34] THIELE-BRUHN, S., SEIBICK, T., SCHULTEN, H.R., LEINWEBER, P. Sorption of sulfonamide pharmaceutical antibiotics on whole soils and particle-size fractions. J. Environ. Qual. [online]. 2004, vol. 33, pp. 1331-1342. Available from: https://doi.org/10.2134/jeq2004.1331.

[35] THIELE, S. Adsorption of the antibiotic pharmaceutical compound sulfapyridine by a long-term differently fertilized loess Chernozem. J. Plant Nutr. Soil Sci. [online]. 2000, vol. 163, pp. 589-594. Available from: https://doi.org/10.1002/1522-2624(200012)163:6<589::AID-JPLN589>3.0.CO;2-5.

[36] ZHI, D., YANG, D., ZHENG, Y., YANG, Y., HE, Y., LUO, L., ZHOU, Y. Current progress in the adsorption, transport and biodegradation of antibiotics in soil. J. Environ. Manage. [online]. 2019, vol. 251, ID 109598. Available from: https://doi.org/10.1016/j.jenvman.2019.109598. 
[37] BIALK, H.M., PEDERSEN, J.A. NMR investigation of enzymatic coupling of sulfonamide antimicrobials with humic substances. Environ. Sci. Technol. [online]. 2008, vol. 42, pp. 106-112. Available from: https://doi.org/10.1021/es070779d.

[38] KLUČÁKOVÁ, M., PEKAŘ, M. Transport of copper(II) ions in humic gel - New results from diffusion couple. Colloid. Surface. A [online]. 2009, vol. 349, pp. 96-101. Available from: https://doi.org/10.1016/J.COLSURFA.2009.08.001

[39] SEDLÁČEK, P., SMILEK, J., KLUČÁKOVÁ, M. How Interactions with polyelectrolytes affect the mobility of ionic dyes in hydrogels - Results from diffusion cells. React. Funct. Polym. [online]. 2013, vol. 73, pp. 1500-1509. Available from: https://doi.org/10.1016/j.reactfunctpolym.2013.07.008.

[40] KLUČÁKOVÁ, M., KALINA, M., SMILEK, J., LAŠTƯVKOVÁ, M. The transport of metal ions in hydrogels containing humic acids as active complexation agent. Colloid. Surface. A [online]. 2018, vol. 557, pp. 116-122. Available from: https://doi.org/10.1016/j.colsurfa.2018.02.042.

[41] KLUČÁKOVÁ, M. Agarose hydrogels enriched by humic acids as complexation agent. Polymers [online]. 2020, vol., 12, pp. 687-698. Available from: https://doi.org/10.3390/polym12030687.

[42] KLUČÁKOVÁ, M., KALINA, M. Diffusivity of $\mathrm{Cu}(\mathrm{II})$ ions in humic gels - influence of reactive functional groups of humic acids. Colloid. Surface. A [online]. 2015, vol. 483, pp. 162-170. Available from: https://doi.org/10.1016/j.colsurfa.2015.05.041.

[43] KLUČÁKOVÁ, M., KALINA, M., SEDLÁČEK, P., GRASSET, L. Reactivity and transport mapping of Cu(II) ions in humic hydrogels. J. Soil. Sediment. [online]. 2014, vol. 14, pp. 368-376. Available from:

https://doi.org/10.1007/s11368-013-0730-2.

[44] KLUČÁKOVÁ, M., PEKAŘ, M. New model for equilibrium sorption of metal ions on solid humic acids. Colloid. Surface. A [online]. 2006, vol. 286, pp. 126-133. Available from:

https://doi.org/10.1016/J.COLSURFA.2006.03.013. 